\title{
Parent-practitioner engagement in preschool education and the threat of negative thinking about the poor across England and the USA
}

\begin{tabular}{|c|l|}
\hline Journal: & Research in Education \\
\hline Manuscript ID & RIE-19-0042.R2 \\
\hline Keywords: & $\begin{array}{l}\text { Family, school, and community, Social justice, Inequality, } \\
\text { Marginalisation, Pedagogy, Policy }\end{array}$ \\
\hline Abstract: & $\begin{array}{l}\text { Parent-practitioner engagement in the early years has become a key } \\
\text { policy in remediating the negative effects of poverty upon children's } \\
\text { early educational outcomes. Although this approach is shared across } \\
\text { several developed countries there has been limited attention upon how } \\
\text { practitioners think about poverty and their engagement with parents in } \\
\text { poverty. Our mixed methods study in England and the USA provides rare } \\
\text { evidence addressing these issues. Among our practitioners in both } \\
\text { countries 'parent blame' for poverty featured to some extent in the } \\
\text { accounts of a majority of practitioners. We also found a relationship } \\
\text { between the extent to which our practitioners felt individual parents are } \\
\text { culpable for poverty and their reporting of more negative engagement } \\
\text { with parents - particularly in England. We claim this is worthy of further } \\
\text { study as a potential threat to the 'child-parent-practitioner triangle' and } \\
\text { to remediation of poverty's effects within early educational contexts. }\end{array}$ \\
\hline
\end{tabular}

\section{SCHOLARONE Manuscripts}





\section{Parent-practitioner engagement in early education and the threat of negative thinking about the poor across England and the USA}

\section{Introduction}

This article describes research which aimed to develop knowledge about early childhood education and care (ECEC) practitioners' engagement with parents in poverty. Measured by income thresholds in both countries living in poverty is a significant problem as it is highly predictive of negative educational consequences for children. Across both England and the USA over twenty percent of children are living in poverty and there are sizable and persistent income-related gaps in children's early educational outcomes before they enter school (Dickerson and Popli, 2014; Waldfogel and Washbrook, 2011: 1; Stout Sasinsky, 2013). Several research studies also show the negative impact of poverty upon parental investment and children's experiences as they grow up in England and the USA (Richards et al, 2016: 43; Bassok et al, 2016: 1). We begin by showing how in both countries there has been a policy emphasis on ECEC engaging parents as a means of remediating these problems attached to poverty (Schweinhart et al., 2005; Love et al., 2005; Field, 2010; Allen, 2011; Mathers and Smees, 2014). While a focus upon parental engagement should not distract from critical scrutiny of the context of recent funding cuts in both countries and their implications for disadvantaged children (Alston, 2017; Alston, 2018), we highlight how research suggests engagement has benefits. We move on to show, though, how policy around parental-engagement is not value-neutral in either country with a negative construction of parents in poverty framing it. Indeed, we note engagement is further complicated by its contingent nature and the influence of practitioners' perceptions of poverty and disadvantage. Below we draw on rare data from practitioners in several locations across England and the USA which reveals how they shared a negativity expressed about disadvantaged parents found in policy discourse. We argue this is a threat to engagement and the important 'child-parent-practitioner triangle' in the early years.

\section{Policy, parenting and ECEC}

Since the new millennium began many governments across the globe have prioritized family policy as a mechanism for tackling social ills such as poverty (OECD, 2012; Faircloth et al., 2013). There are differing national trends in how the significance of family has emerged (Faircloth et al., 2013). In the United Kingdom (UK) and the United States of America (USA) - the contexts focused upon in this article - politicians have moved away from an earlier resistance to supporting policies which encroach too extensively into family life. The UK government and the US Federal government, along with individual States, have become increasingly active in family and parenting policy to support interventionist approaches in the last two decades (Eisenstadt and Oppenheim, 2019: 148; Wilinski and Morley, 2019). Some differences between the policy approaches adopted by successive UK governments is evident (Eisenstadt and Oppenheim, 2019). Similarly, in the USA variation in family policy approaches between States is evident (DHHS \& DE, 2016). There is, however, one common feature of family policy between the UK and USA that runs through the period since the millennium began. This has been growing emphasis upon early childhood education and care 
(ECEC) as a core part of provision which can support parents and children (Eisenstadt and Oppenheim, 2019: 105; Wilinski and Morley, 2019). DHSS \& DE, 2016: 1).

Within both countries there is also a specific emphasis on ECEC engaging parents in poverty. The UK's first Child Poverty Strategy, for example, mentions 'empowering' ECEC services and practitioners 'to do more for the most disadvantaged' via the provision of free early education places for children aged 2-5. A current plan to tacklea lack of social mobility has emphasised the engagement of parents in poverty with early years practitioners in the delivery of 'evidence-based home learning environment programmes that support early language development' (DfE. 2017a: 12; HMG, 2018). Early educational curricula in both England and the USA emphasise parents' active engagement with practitioners in their children's education to ensure their 'school readiness'. This engagement is described as 'essential' (NYSED, ONLINE. 8; Ohio DoE, ONLINE) via 'partnership working' (DfE, 2017b: 5). In the USA the Waron Poverty and No Child Left Behind campaigns both set out to target parental engagement with practitioners in children's early learning (won Kim, 2019: 2). Federal programmes such as Early Head Start and Head Start are targeted at the poor and place an emphasis upon parental engagement as an important factor in the development of young children (Ansari and Gershoff, 2015: 562; Nix et al, 2018: 106). Many States have actively supported an emphasis on parental engagement which locates low income families as the subjects of intervention by expanding Pre-K (PreKindergarten) and other ECEC provision (Stark, 2010; Wilinski and Morley, 2019).

Via engagement with families in poverty it is expected ECEC in both countries can reduce pressures on parents by helping support their resourcefulness and resilience when parents are trying to protect their children from risks attached to living in adverse circumstances. There is an expectation ECEC can improve capabilities by 'helping parents to parent'. In this way it is hoped practitioners engaging with parents in poverty can support children's learning (Smith, 2018: 28) and reduce existing 'attainment gaps' (DWP \& DfE, 2011: 35). Moss $(2014,3)$ highlights this logic - invest in ECEC so it can engage with parents and you will get high returns on investment including children's improved academic performance and school readiness. These are considered essential to later achievement in school and beyond. As will be highlighted such engagement is potentially beneficial, although it is not straightforward or value-neutral.

\section{The benefits of parent-practitioner engagement in ECEC}

There is significant research, nationally and internationally, showing parental engagement in children's learning is positively related to achievement (Campbell, 2011: 6 ). This is true of all phases in education including the early years (won Kim, 2019). The significance of engagement between parents/carers and early education practitioners has become 'well established' across several developed countries (Mahmood, 2013: 55) - including England and the USA (Draper and Wheeler, 2010; Bierman et al, 2017). Engagement of parents can be in preschool setting life generally and more specifically it can be in their children's learning. Traditionally, therefore, it has involved variety and can include parents working with staff in settings and parents as governors or on management committees. Parents can also become involved in the design and shaping 
of workshops and courses. Parents can run services such as toy libraries while sharing observations and jointly planning next steps for their child's learning with practitioners (Draper and Wheeler, 2010: 180). This responsibility for their children's learning, intellectual development and educational success has become a key remit of parenting in early childhood across most developed countries since the turn of the millennium and it is this outcome parents are increasingly expected to support through engagement with early years practitioners (Smyth, 2015: 731).

Practitioners become engaged with parents in their child's learning via their general practice, through 'parent pedagogy' and when providing skills provision designed tohelp parents better support children (Draper and Wheeler, 2010; Ward, 2013; Jensen, 2018). When involved in engagement research reveals parents prefer co-construction and joint-involvement with practitioners. They want to be listened to, respected and have their views and knowledge taken seriously (Draper and Wheeler, 2010; Vandenbroeck 2014). Practitioners are expected to ensure that a trusting, respectful relationship develops from the initial contact with all parents and that the early educational environment is warm and welcoming to all parents. As Owen (2017: 476) notes, best practice expects an 'inclusive perception' will pervade the thinking of practitioners which involves 'the acknowledgement and celebration of difference, rather than its problematization'.

\section{Parent-practitioner engagement, values and the poor}

Policy concerning parental engagement focused upon parents in poverty is not valueneutral. Rather, it is the product of the prevailing political context within which it is developed and differing political constructions of child poverty are important in this regard. Some consider child poverty a structural issue caused by economic divisions and issues attached to low income and the labour market (Rank 2011; Eppard et al, 2017). Lack of access to economic resources means parents are restricted when investing materially in their children's education and they experience financial stress compromising family relationships and attachments with children (Cooper and Stewart, 2013; Stock et al, 2014). A second explanation for poverty supported by neoliberal polity, though, has become influential and focuses upon the behaviours of the poor rather than wider economic forces. From this perspective poverty is expressed in the form of unacceptable behaviours deviating from the 'respectable' behavioural norms of dominant society, for instance as the lifestyle of a subculture or 'underclass'. The inadequacy of people's power over financial and other resources is seen as irrelevant to the question of how they behave (Veit-Wilson, 2000).

Constructing child poverty as a problem of the negative behaviours of the poor has allowed for it to be made amenable to treatment via ECEC. Gillies (2008) notes how in England the political rhetoric of successive governments around parental engagement via ECEC reveals a common class specific focus on disadvantaged parents as failing their children. Poverty is constructed within policy discourse as a problem of the 'troubled' behaviours of the poor with parents in poverty 'reproducing a cycle of deprivation and anti-social behaviour' (Gillies, 2008: 1079). As such, a prominent focus of ECEC's engagement with parents in poverty has been an expectation it can address parenting deficiencies and alter their negative behaviours (Gillies et al, 2017; Jensen, 
2018; HMG, 2018: 7). Similarly, in the USA, Wilinski and Morley (2019: 5) observe how parental engagement in ECEC can be conceptualised in two ways - 'doing with' and 'doing to'. It is the latter which has increasingly become the focus of parental engagement with low income parents as they receive interventions with class-based and cultural assumptions designed to improve deficient parenting by extending the school learning environment into the homes of the poor.

\section{Practitioners and their views about poverty and the poor}

Parental-engagement is not straightforward and often poses a challenge, particularly when engaging those labelled 'hard-to-reach parents' including those in poverty (Campbell, 2011). The personal views of practitioners and how they perceive and interact with parents are important to engagement (Ward, 2013: 13). It is recognised how ECEC practitioners having 'positive attitudes' towards parents increases their levels of engagement (Knopf and Swick, 2007; Ward, 2013). ECEC practitioners' views about parents in poverty are important in their efforts to engage such parents. ECEC practitioners are unlikely to be immune to the negative constructions evident in policy mentioned earlier. Research suggests these are held by the wider population. 'Parent blame' is a central feature of these representations of the poor in both countries (Rose and Baumgartner, 2013; Hall et al, 2014; Howard et al, 2017; Shildrick, 2018; Jensen, 2018). Despite the potential significance of ECEC practitioners' views about parents in poverty however, research on these issues is extremely limited.

There are some small-scale studies which have considered practitioners narratives about poverty. For instance, an exploratory qualitative study by Ipsos Mori with practitioners holding varied job roles found their views on the causes of poverty ranged from 'material circumstances to parenting attitudes and behaviours' (Cameron et al, 2008: 9). Similarly, recent qualitative research within integrated preschool settings in the South-East of England found a complex range of responses among 38 practitioners when asked about the poor. These included negative notions about the undeserving poor (Lyndon, 2019). Smith (2018) focused upon views held by practitioners about parents and their links to practice. It explored how mothers experienced the resources provided by a small town in the East Midlands of England to support their children's literacy development and spoke with preschool staff involved. It found that practitioners held more negative views about those mothers from social-housing estates and blamed these mothers for their children not being 'school ready'. This shaped very different provision designed to engage them in supporting their children's literacy compared with provision for other mothers. Several of the mothers and carers from the social housing estates felt stigmatized and this negatively affected attendance among them (Smith, 2018: 28-29). Similarly qualitative research in Turkey examining the processes around parental engagement in preschool activities also found 'negative attitudes' and 'the behaviour of teachers' were 'important problems' which negatively affect relations with parents in poverty (Kocyigit, 2015).

As indicated, though, evidence about practitioners' views on poverty and how these may link to engagement remains rare. Despite this, there is growing recognition that engaging with parents in poverty is dependent upon well-educated and competent staff. A lack of pre-service training in this respect can be problematic (Peters and Shamahd, 
2014: 412). Mahmood's research (2013: 5) rightly highlights how ECEC practitioners should not be 'presumed to be responsible for lack of parent-teacher collaboration' and how some parents are not responsive. Mahmood, however, also indicates the importance of competent staff without negative attitudes when it comes to working with parents in poverty. Addressing the lacuna in the evidence base, below we provide modest but unique evidence which has explored transnationally the views of ECEC practitioners about the causes of poverty and how these relate to engagement with parents in poverty. To the best of our knowledge, it is the first study to do so across two countries.

\begin{abstract}
Methodology
A mixed methodology comprising a quantitative survey strand and a qualitative interview strand was used to achieve the research aim and answer the research questions mentioned earlier. Below we will make no claim to our sample being representative of the wider ECEC workforce in England and the USA. Our ability to generalize the findings is therefore limited. To our knowledge, however, this is the first study to examine the relationship between general perceptions of the causes of poverty and ECEC practitioners' perceptions of, and involvement with, parents in poverty. Sowe adopt 'moderatum generalization' below with our conclusions being 'testable propositions that might be confirmed or refuted through further evidence' (Payne and Williams 2005, 296). Interviewing was with ECEC practitioners. Overall 60 semistructured interviews with ECEC practitioners were undertaken in both countries. Across England 30 interviews with ECEC practitioners were completed in Teesside $(n=10)$, Worcestershire $(n=10)$ and Northants $(n=10)$. These 3 English locations were selected via variation sampling to include practitioners working in relatively urban and rural contexts (e.g. more urban Teesside and more rural Worcestershire and Northamptonshire). Across the USA 30 interviews with ECEC practitioners were also completed in New York $(n=20)$ and Ohio $(n=10)$. These US locations were based on convenience as contacts with academics were established in these locations.

Practitioners were selected for interview purposefully and had to work with children living in poverty according to the income thresholds for households in both Englandand the USA. Given the large percentages of children experiencing poverty in both countries (in England 30\% and in the USA 21\% using a threshold some consider to be far too low - see Tilly, 2019) it is difficult to find ECEC practitioners that do not work with children and parents in poverty. Interviewees were asked to confirm they worked with children in poverty before being interviewed. The questionnaire also included an introduction which made clear it was only to be completed by those working with children in poverty living in households below the income thresholds for poverty in both countries. In the USA it was also targeted at practitioners in settings known to work with parents in receipt of Federal and state assistance programs. Practitioners also had a relatively high status as ECEC practitioners - e.g. Pre-Kindergarten teachers in the USA and Senior Practitioners (level 5 or above in the national qualifications framework) in England.
\end{abstract}

The questionnaire was administered online via a popular established online survey software package. Within England a link to the online questionnaire was sent to practitioners completing programmes at level 5 and above at the English authors' 
respective Universities. The link to the online questionnaire was sent to around 500 such practitioners. In the USA the link to the questionnaire was sent via emails to a list of early years settings obtained online and via personal contacts. This approach made it impossible to calculate a precise response rate; however, the purpose of the present study was merely to explore the relationship between poverty beliefs and perceptions of parents in poverty in a reasonable sample of experienced practitioners. Participation was completely voluntary, and no incentives for study completion were provided. In total 338 questionnaires were returned from practitioners (159 from the USA and 179 from England).

The qualitative semi-structured interview strand considered in-depth the views of practitioners about the causes of poverty and their experiences attached to their work with parents in poverty. The interview guide was constructed around themes focusing upon practitioners' backgrounds, roles both general and relating to parents and children in poverty, meanings attached to poverty and its causes, and work with/support for parents and children in poverty. The quantitative questionnaire was constructed with several blocks covering themes of interest. It started with a section containing nine variables concerning beliefs about the causes of poverty. Five variables portrayed poverty as being due primarily to individual-based factors, (e.g., "People who are exposed to chronic/generational poverty generally only have themselves to blame."). The remaining four items portrayed poverty as being due primarily to situation-based factors, (e.g., "Chronic/generational poverty is primarily maintained by factors that are largely beyond the control of the individuals in question."). All items on these variables were responded to using nine-point scales (1 = "strongly disagree"; 9 = "strongly agree"). A further section asked practitioners to respond to four statements regarding their involvement with parents/carers living in poverty: "regularly attend conferences", "volunteer in the classroom", "are responsive to communications", "are engaged in child's learning/development" - each measured on a 9 point scale ( 1 = "strongly disagree"; 9 = "strongly agree").

The quantitative analysis of questionnaire data involved descriptive and inferential statistics. For purposes of the analysis, the nine variables on the poverty belief scales were combined and then averaged into a composite measure for individualistic and situational beliefs. In doing so the reliability coefficient indicated a good level of interitem consistency $(\alpha=.78)$. Similarly, the four variables indicating involvement with parents were also averaged into a composite and were highly interrelated $(\alpha=.86)$. Qualitative theme analysis was completed using Nvivo software categorising themes of interest such as poverty beliefs and work with parents in poverty and the exploration of links between these themes. Ethical approval for the project was gained from relevant Research Ethics Committees of participating universities. All practitioners participating within both the quantitative and qualitative strands of the research across both countries provided informed consent and were given guarantees about confidentiality, anonymity and privacy. Pseudonyms are used below.

\section{Findings}

Causes of poverty and pervading 'parent blame' 
We found a level of complexity in responses from practitioners when asked about the causes of child poverty. Although Table 1 shows in both countries situational factors were agreed to be more important than individual factors in causing poverty (measured on the scale 1 = "strongly disagree" up to 9 = "strongly agree"), there was little mention of inequality attached to economic structural factors. Rather, open responses to the survey questionnaire and via interviews revealed how chief among situational factors was a 'cycle' of poverty'. Practitioners implied there is transmission of negative values and behaviours via socialization across generations and this results in a learned helplessness amongst parents which prevents them taking actions to escape poverty. Table 1: Poverty Beliefs by Nation

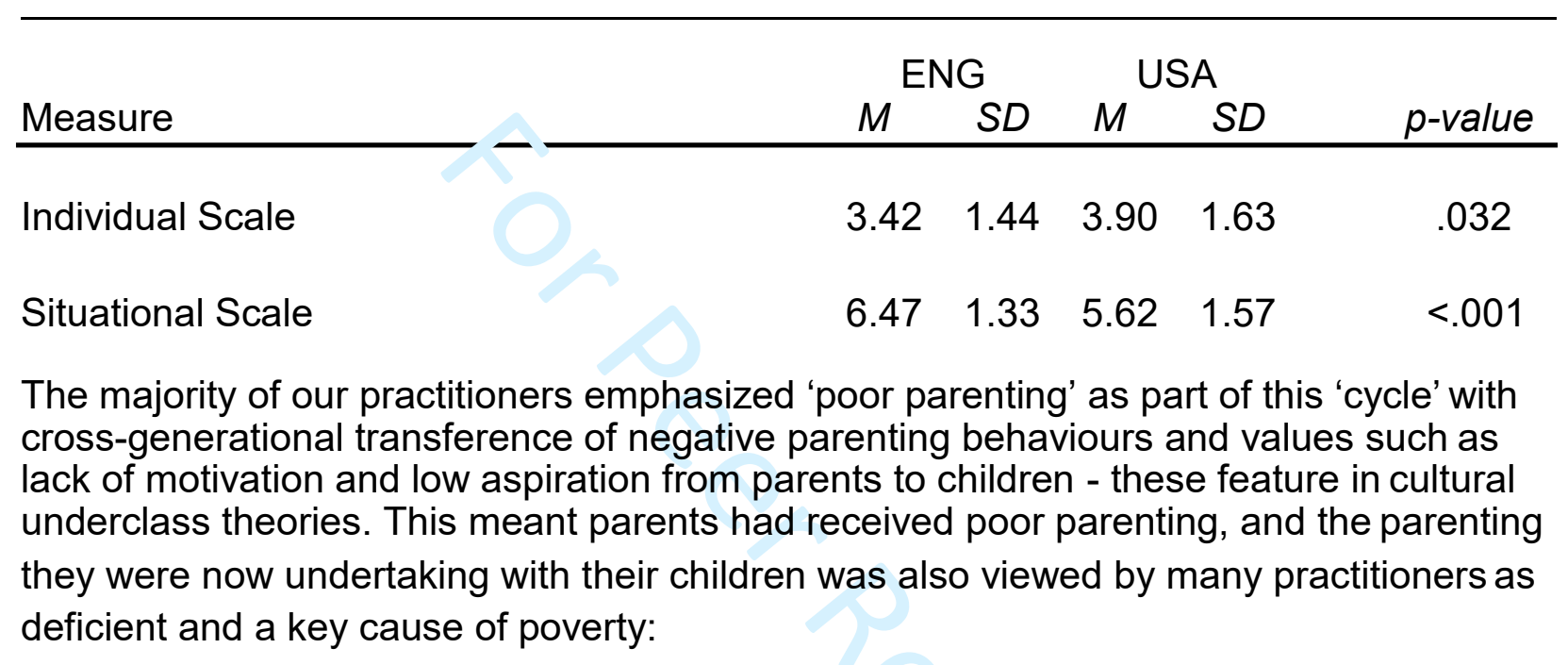

England - Zara -- l've seen a lot of instances where parents and their children are in poverty because their parents were in poverty and they haven't had the help necessarily, from the generations before them.

England - Sadie - the lack of parental skills, that lack of support for the children and the fact that we've got families who are in a cycle where two or three generations have never worked and so you have children in the school who are in that cycle of poverty.

USA - Leonard - I think it is a cycle. It's, you know they are in poverty, their parents grew up in poverty, and it just continues

USA - Katlyn - Lack of knowledge. We can start to talk about how they may have had generations of lack of knowledge as parents where they weren't taught correctly, but the buck needs to stop somewhere, the cycle needs to re-start somewhere.

Accordingly, 'parent blame' popular in England and the USA as an explanation for poverty was to the fore in the responses of our practitioners. Indeed, several interviewees indicated how they believe the central cause of poverty is rooted in the 
failings of individual parents and their negative behaviours. These practitioners accentuated what they considered to be parent's deficiencies, irresponsibility and poor choices:

England - Selena - For me the biggest factor, the biggest contributing factor for child poverty is parental engagement or involvement with their children and their aspirations for their children.

England - Anne - I think it's the choice of the parents of why they're living in poverty. I don't think it's anybody else's fault apart from them... I think it's about how they use the money... They spend it on things that they don't need.

England - Laura - When they [parents] are getting the money in, they're choosing to spend it on other things that aren't helping their children - so the Sky TV. I'm a mam [mother] and I wouldn't dream of letting my children go hungry, and not going to school with shoes on, for something that I wanted.

USA - Wendy - Bad choices, poor choices... it boils down to choices. In your control, out of your control.

USA - Yolanda - A lot of parents they ignore children, and that leads to poverty.

USA - Doris - poor choices, that the parents made and that automatically puts the child in this situation that they really have no control over which isn't fair to them.

Only a minority of practitioners in the qualitative data mentioned structural issues around the economy as explanations for the causes of poverty. Very few interviewees made any reference to historical and recent changes to the economy and labour markets, austerity policies and welfare reforms in both countries. This was also true in regard to the feminization of poverty which has also been highlighted in recent years (EHRC, 2018) When labour market issues were mentioned it was usually alongside further explanations which prioritized 'parent blame' attached to cultural deprivation:

England - Zoe - sometimes families can't help the circumstances that they're in or that they get into. I think when parents become unemployed. And I think sometimes, as much as I hate to say it, it does run in generations... I've seen a lot of instances where parents and their children are in poverty because their parents were in poverty and they haven't had the help necessarily, from the generations before them.

USA - Danielle - probably lack of jobs, or lack of the will to work maybe in some cases even, and then just poor choices maybe, that the parents made and that automatically puts the child in this situation that they really have no control over which isn't fair to them.

\section{Negativity and engagement with parents in poverty}


As mentioned earlier, the negativity expressed above about parents and their parenting is important as practitioners' views of parents 'have an impact on the way they perceive and interact with them'. Indeed, with regard to the 'child-parent-practitioner triangle' in the early years it is identified how 'in any situation it would be very hard to build trusting and supportive relationships if one partner held negative or misplaced views of the other' (Ward, 2013: 13). Our quantitative data from the closed questions in our survey, and qualitative data from the survey's open questions and our interviews, highlighted practitioners' negative views about the engagement of parents in poverty within ECEC. Via the online survey, practitioners responded to four statements regarding their views and interactions with the parents living in poverty. They were asked about the extent to which they agreed these parents "regularly attend conferences", "volunteer in the classroom", "are responsive to communications", and "are engaged in child's learning/development". Each measure was on a scale from 1 (strongly disagree) through to 9 (strongly agree). Table 2 reports their responses.

\section{Table 2: Attitudes to Parents in Poverty by Item by Nation}

\begin{tabular}{lllllll}
\hline & \multicolumn{4}{c}{ ENG } & \multicolumn{4}{c}{ USA } & \\
Measure & $M$ & $S D$ & $M$ & $S D$ & $p$-value \\
\hline Attitudes to Parents in Poverty & & & & & \\
$\quad$ Regular Conferences & 3.06 & 1.89 & 3.39 & 2.15 & .260 \\
$\quad$ Volunteer in Classroom & 2.65 & 1.75 & 3.18 & 2.11 & .060 \\
$\quad$ Responsive to Communications & 3.42 & 1.86 & 3.91 & 1.87 & .073 \\
$\quad$ Engaged in Child's Learning & 3.45 & 1.83 & 3.95 & 2.15 & .085 \\
& & & & & \\
\hline
\end{tabular}

Table 2 shows within both countries practitioners responding to the survey were negative about parental engagement with disagreement being the average across all four measures. The practitioners in England perceived parental engagement a little more negatively across the measures than their counterparts in the USA, although, between countries slight differences in means were not statistically significant. What was quite startling within the qualitative data was the conscious way some practitioners expressed their negativity towards parents in poverty when discussing their attempts to engage them - several revealed this was a challenge and what one called 'the hard bit'. Those attaching blame to parents in poverty for their poverty appeared also to accentuate the need for parents' compliance and acceptance of treatment prescribed to eliminate their deficiencies. Consequently, several practitioners' described approaches to engaging parents in poverty which were focused mostly upon the parent rather than the parent-child relationship, were hierarchical rather than reciprocal, and were very much a top-down process. In a context where academic discourses, theory and good practice guidance emphasize joint involvement and co-construction if parents from all backgrounds are to be successfully engaged, several practitioners made it clear they were first among un-equals and were addressing deficiencies when it came to working with parents in poverty. The knowledge of parents in poverty was rarely mentioned as an asset: 
England - Karissa - the Children's Centre does a lot to help with parenting skills but unfortunately some parents aren't so educated and they have trouble raising their children.

England - Clare - we can educate the parents... They need the [pedagogical] support to be able to parent effectively.

England - Anne - I think they should be made to go to classes for their benefit [welfare payments]... to have them all build up their self-esteem... just giving them a better positive mental attitude

England - Dolores - you try and get them onto courses to better themselves... And as much as you try and show them the right steps... they generally don't take the opportunities that are there for them.

England - Sacha - They [parents in poverty] just come [to parenting provision] because they think they should. Not because they're thinking it will benefit their children... they see it as a babysitting service.

USA -- Nina - It depends on the parents' attitude. Do they want to take the advice? You have to have the parent support and parent willingness. I would say nobody wants to be told there is something wrong.

USA - Yvette - Some families seem to not be able to change the course of their family history... I do see my role as helping parents understand.

USA - Wendy - I've worked with parents in poverty who are concerned about their children... But I can also see that without a support system it would be very difficult for them to do those things - because that's not your norm.

Via our survey we explored if those practitioners believing poverty is primarily due to individual factors also reported less involvement with parents in poverty. As indicated earlier, variables in our poverty belief scales were combined and then averaged into a composite measure for individual and situational beliefs about the causes of poverty. Similarly, the four variables in Table 2 indicating parental engagement were also averaged into a composite. Tables 3 and 4 below indicate how there was, at least to some extent, a linear correlation between views on the causes of poverty and selfreported levels of involvement with parents in poverty. Those practitioners who more strongly attributed poverty to individual factors reported lower levels of involvement with parents in poverty. The data also reveal how those who attributed the causes of poverty to situational factors reported more positive levels of involvement with parents in poverty. These correlations were stronger in the English sample.

Table 3: Correlation between the Engagement Composite and the Poverty Beliefs Individual Composite 
Table 4: Correlation between the Engagement Composite and the Poverty Beliefs Situational Composite

\begin{tabular}{cccc} 
Measure & Overall & ENG & US \\
\hline Engagement Composite & -.03 & -.13 & .06 \\
\hline
\end{tabular}

\begin{tabular}{llll} 
Measure & Overall & ENG & US \\
\hline \multicolumn{1}{c}{ Engagement Composite } & $.20^{*}$ & $.29^{*}$ & .18 \\
${ }^{*} p<.01$ & & & \\
\hline
\end{tabular}

This is interesting because it does suggest reported differences in levels of engagement with parents in poverty are indeed tied, at least to some extent, with general poverty beliefs. A parsimonious explanation of this finding is belief poverty is caused by individual-level factors creates a bias against the poor which has some degree of influence on engagement with parents in poverty. While some practitioners in our study sent food parcels home with children the latter were very much seen as innocent victims but this was less the case with their parents. Indeed, one of the interviewees in England vividly highlighted the challenge of changing negative views about parents in poverty:

England - Sharon - I don't know whether I should share this but I will. One of my staff is pregnant at the moment. She's due to leave. And a parent of one of the deprived children is also pregnant. And she's found out she's having a little girl. She's [the parent's] got all boys. So she came in the other day with this huge bag of clothes for my member of staff cause she said, "I'm not having a boy and you are." And my member of staff refused to even put the bag in her car because of the family it came from. And I just thought, that is just so wrong because your perception of that family. There was nothing wrong with the stuff. It was lovely and clean. Most of it was brand new. But she wouldn't even open the bag and look in it. And that really breaks my heart. It really does.

\section{Conclusion}

ECEC alone cannot address the negative effects of poverty in the early years, but it can help support parents facing extremely challenging circumstances in which raising 
children is made much more difficult. The 'child-parent-practitioner triangle' is key in ECEC and particularly important when working with poverty. Building relations with parents, though, is not easy and is broadly accepted to work best when reciprocity is evident - i.e. joint involvement, mutual respect and influence - and therefore practitioners' views are important in this respect. We found a good deal of negativity expressed towards parents in poverty by the practitioners providing data for our research. We also found, particularly in England, the practitioners believing poverty is a result of fallible choices made by individuals harboured more negative opinions of disadvantaged parents and reported less involvement with these parents. As indicated, we must be cautious in attaching wider relevance to our findings, though we do believe our research is unique and important in the context where ECEC is expected to play a role in remediating child poverty and practitioners work with parents in poverty is a key element of this work. Parents may be unresponsive to practitioners, but given that parents in poverty already struggle with a long list of challenges and disadvantages, these issues deserve further empirical attention. Our findings, when viewed alongside those from other recent research, suggest professional development connected to working with parents in poverty needs priority.

This is not straightforward. Peters and Shamahd's (2014) research demonstrates the importance of such in-service professional development for ECEC practitioners who work with children and parents from disadvantaged backgrounds. They highlight the challenges involved and the need for pedagogical support which is sustained over long periods of time and developed by specialized staff (such as pedagogical coaches). Such training also needs to be organized in a comprehensive way. Owen's (2017:476) study in England explored the reversing of deficit-based discourses amongst practitioners and the promotion of 'diversity gain' in seven early years settings in England. It supports the use of a 'critical communicative methodological approach' with an emphasis upon exploration and listening for understanding if 'authentic inclusion' of parents in poverty is to be achieved. It also highlighted how 'practitioners felt that there was a distinct lack of resources, including funding, time and expertise, to support inclusive practice appropriately'.

\section{Acknowledgements}

We are grateful to all the practitioners providing data for our research. We also express gratitude to The British Academy and The Society for Educational Studies for providing financial support which facilitated the development of the research.

\section{References}

Allen, G. (2011) Early Intervention: The Next Steps: An Independent Report to Her Majesty's Government, London: Cabinet Office

Alston, P. (2017) Statement on Visit to the USA, by Professor Philip Alston, United Nations Special Rapporteur on extreme poverty and human rights. Accessed on

20:01:19 at

https://www.ohchr.org/EN/NewsEvents/Pages/DisplayNews.aspx?NewsID=22533 
Alston, P. (2018) Statement on Visit to the United Kingdom, by Professor Philip Alston, United Nations Special Rapporteur on extreme poverty and human rights. Accessed om 20:01:18 at

https://www.ohchr.org/EN/NewsEvents/Pages/DisplayNews.aspx?NewsID=23881\&Lan $\underline{g I D}=\mathrm{E}$

Ansari, A. and Gershoff, E. (2015) 'Parent Involvement in Head Start and Children's Development: Indirect Effects Through Parenting', Journal of Marriage and Family, 77(2), pp 562-579

Bassok, D., Finch, J. E., RaeHyuck, L., Reardon, S. F., \& Waldfogel, J. (2016) 'Socioeconomic gaps in early childhood experiences, 1988 to 2010', AERA Open, 2(3), $1-22$.

Bierman, K.L., Morris, P.A., Abenavoli, R.M. (2017) Parent Engagement Practices Improve Outcomes for Preschool Children, Edna Bennett Pierce Prevention Research Center, Pennsylvania State University.

Campbell, C. (2011) How to reach hard-to-reach parents: encouraging meaningful parental involvement with schools, Nottingham: National College for School Leadership

Cooper, K. \& Stewart, K. (2013) Does money affect children's outcomes? A systematic review, York: Joseph Rowntree Foundation

Cameron, D., Fryer-Smith, E., Harvey, P. and Wallace, E. (2008) Practitioners' Perspectives on Child Poverty, Research Report No DCSF-RR058, London; Department for Children, Schools and Families

DfE (Department for Education) (2017a) Unlocking Talent, Fulfilling Potential: A plan for improving social mobility through education, London: Her Majesty's Stationery Office DfE (Department for Education) (2017b) Statutory framework for the early years foundation stage, London: DfE

Dickerson, A, Popli, G. (2014) Persistent poverty and children's cognitive development: Evidence from the UK Millennium Cohort Study, Sheffield Economic Research Paper Series 2011023, Sheffield: University of Sheffield

U.S. Department of Health and Human Services \& U.S. Department of Education (2016) Policy statement on family engagement from the early years to the early grades. Accessed on 19:01:19 at: https://www2.ed.gov/about/inits/ed/earlylearning/files/policystatement-on-family-engagement.pdf

Draper, L, Wheeler, H, (2010) 'Working with parents'. In G Pugh, B Duffy (eds) Contemporary issues in the early years (5th edn), London: Sage Publications, 179-92

DWP (Department for Work and Pensions) and DfE (Department for Education) (2011) A new approach to child poverty: Tackling the causes of disadvantage and transforming families' lives, London: DWP and DfE 
Eisenstadt, N. \& Oppenheim, C. (2019) Parents, Poverty and the State, Bristol: Policy Press

EHRC (Equality and Human Rights Commission) (2018) Is Britain Fairer? The State of Equality and Human Rights 2018, Accessed on 19:01:19 at:

https://www.equalityhumanrights.com/en/britain-fairer

Eppard, M., Chomsky, N., Rank, M. \& Brady, D. (2017) 'On Culture, Politics, and Poverty'. Contexts, 16(4), pp, 8-11

Faircloth, C., D. Hoffman, and L. Layne. (2013) Parenting in Global Perspective: Negotiating ideologies of kinship, self and politics, London: Taylor \& Francis.

Field, F. (2010) The foundation years: Preventing poor children becoming poor adults, London: Cabinet Office.

Gillies, V. (2008) 'Childrearing, class and the new politics of parenting, Sociology Compass', 2(3), 1079-95

Gillies, V., Edwards, R. \& Horsley, N. (2017) Challenging the politics of early intervention: Who's 'saving' children and why, Bristol: Policy Press

Hall, S., Leary, K. and Greevy, H. (2014) Public Attitudes to Poverty, York: Joseph Rowntree Foundation

Her Majesty's Government (2018) Improving the Home Learning Environment, London: Department for Education

Howard, C., Freeman, A., Wilson, A. and Brown, E. (2017) "The Polls - Trends:

Poverty", Public Opinion Quarterly, 81(3), pp 769-89

Knopf, H. and Swick, K. (2007) 'How parents feel about their child's teacher/school: Implications for early childhood professionals', Early Childhood Research Journal. 34(4). 291-296

Kocyigit, S. (2015) 'Family Involvement in Preschool Education: Rationale, Problems and Solutions for the Participants', Educational Sciences: Theory \& Practice, 15(1), p141-157

Jensen, T. (2018) Parenting the Crisis: The cultural politics of parent-blame, Bristol: Policy Press.

Love, J.M., Kisker, E.E., Ross, C., Raikes, H., Constantine, J., Vogel, C. (2005) 'The effectiveness of early head start for 3-year-old children and their parents: Lessonsfor policy and programs', Developmental Psychology, 41, 885-901.

Lyndon, S. (2019) Early years practitioners' narratives of poverty in early childhood, University of Sussex: Unpublished Educational Doctorate Thesis

Mathers, S.\& Smees, R. (2014) Quality and inequality: Do three and four year olds in deprived areas experience lower quality provision, London: Nuffield Foundation 
Mahmood, S. (2013) 'First-Year Preschool and Kindergarten Teachers: Challenges of Working With Parents', School Community Journal, 23(2), p55-85

Moss, P, (2014) Transformative change and real utopias in early childhood education: $A$ story of democracy, experimentation and potentiality, London: Routledge

New York State Education Department (ONLINE) The New York State Pre-Kindergarten Foundation for the Common Core, Albany: New York. Accessed on 17:01:19 at http://www.p12.nysed.gov/earlylearning/standards/documents/PrekindergartenFoundati onfortheCommonCore.pdf

Nix et al (2018) 'Parent engagement in a Head Start home visiting program predicts sustained growth in children's school readiness', Early Childhood Research Quarterly, 45, pp 106-114

OECD. (2012) Starting Strong III: A Quality Toolbox for Early Childhood Education and Care. Paris: OECD.

Ohio Department for Education (ONLINE) Parents. Accessed on 17:01:19 at http://education.ohio.gov/Parents

Owen, A. (2019) 'Diversity gain? An exploration of inclusive and exclusive perceptions in early years settings in England', Early Child Development \& Care, 189(3), p476-487.

Payne, G. and Williams, M. (2005) 'Generalization in qualitative research', Sociology, $39,2,295-314$

Peters, J. and Shamahd, N. (2014) 'Professional development for ECEC practitioners with responsibilities for children at risk: which competences and in-service training are needed?' European Early Childhood Education Research Journal. 22(3), pp 412-424

Rank, M. (2011) 'Rethinking American Poverty'. Contexts, 10(2), pp. 16-21.

Richards, L., Garratt, E, and Heath, A.F. with Anderson, L. and Altintaş, E. (2016) The childhood origins of social mobility: socio-economic inequalities and changing opportunities, London: Social Mobility Commission

Rose, M., \& Baumgartner, F. R. (2013) 'Framing the poor: Media coverage and U.S. poverty policy, 1960-2008', The Policy Studies Journal, 41, 22-53.

Schweinhart, L. J., Montie, J., Xiang, Z., Barnett, W. S., Belfield, C. R., \& Nores, M. (2005) Lifetime effects: The high/scope Perry Preschool Study through age 40. Monographs of the High/Scope Educational Research Foundation (No. 14), High Scope Press: Ypsilanti, MI.

Shildrick, T. (2018) Poverty Propaganda: Confronting the Myths. Bristol: Policy Press

Smith, H. V. (2018) 'Ready for School?', Society Now, Autumn, 28-29

Smyth, C. (2016) 'Getting Ahead in the Preschool Years: An Analysis of a Preschool Enrichment and Entertainment Market', Sociology, 50(4), 731-747 
Stark, D. R. (2010) Engaged families, effective Pre-K: State policies that bolster success. Washington DC: The Pew Centre on the States.

Stock, L., Corlyon, J., Serrano, C. \& Gieve, M. (2014) Personal Relationships and Poverty: An Evidence and Policy Review. London: Tavistock Institute

Stout Sosinsky, L. (2013) 'Childcare markets in the US: supply and demand, quality and cost, and public policy'. In: Lloyd E and Penn H (eds) Childcare Markets: Can they Deliver an Equitable Service? Bristol: Bristol Policy Press, pp. 131-151.

Tilly, Z. (2019) Defining Away Poverty. Accessed on 01:07:19 at https://www.childrensdefense.org/blog/defining-away-poverty/

Vandenbroeck, M. (2014) Building relationships in unequal relations, Paper delivered at the British Early Childhood Education Research Association's annual conference, February, Birmingham, United Kingdom

Veit-Wilson, J. (2000) 'Horses for Discourses'. In Gordon, D. \& Townsend, P. (eds), Breadline Europe: The Measurement of Poverty. Bristol: The Policy Press, pp 141-164.

Waldfogel, J., \& Washbrook, E. (2011) 'Early years policy’, Child development research, Vol 2011, pp. 1-12.

Ward, U. (2013) Working With Parents in the Early Years, London: Sage Publications

Wilinski, B. and Morley, A. (2019) "Parent Leadership and Voice": How Mid-Level Administrators Appropriate Pre-Kindergarten Parent Involvement Policy. Educational Policy. Accessed on 12:19:19 at https://journals.sagepub.com/doi/abs/10.1177/0895904819864441?journalCode=epxa won Kim, S. (2019) 'Meta-Analysis of Parental Involvement and Achievement in East Asian Countries', Education and Urban Society, 51(5), pp 1-26 
Table 1: Poverty Beliefs by Nation

\begin{tabular}{lcccccc}
\hline & \multicolumn{2}{c}{ ENG } & \multicolumn{2}{c}{ USA } & \\
Measure & $M$ & $S D$ & $M$ & $S D$ & $p$-value \\
\hline Individual Scale & 3.42 & 1.44 & 3.90 & 1.63 & .032 \\
Situational Scale & 6.47 & 1.33 & 5.62 & 1.57 & $<.001$
\end{tabular}

Table 2: Attitudes to Parents in Poverty by Item by Nation

\begin{tabular}{|c|c|c|c|c|c|}
\hline \multirow[b]{2}{*}{ Measure } & \multicolumn{2}{|c|}{ ENG } & \multicolumn{2}{|c|}{ USA } & \multirow[b]{2}{*}{$p$-value } \\
\hline & $M$ & $S D$ & $M$ & $S D$ & \\
\hline Attitudes to Parents in Poverty & & & & & \\
\hline Regular Conferences & 3.06 & 1.89 & 3.39 & 2.15 & .260 \\
\hline Volunteer in Classroom & 2.65 & 1.75 & 3.18 & 2.11 & .060 \\
\hline $\begin{array}{l}\text { Responsive to Communications } \\
\text { Engaged in Child's Learning }\end{array}$ & 3.42 & 1.86 & 3.91 & 2.87 & .873 \\
\hline
\end{tabular}

Table 3: Correlation between the Engagement Composite and the Poverty Beliefs Individual Composite

\begin{tabular}{cccc} 
Measure & Overall & ENG & US \\
\hline Engagement Composite & -.03 & -.13 & .06 \\
\hline
\end{tabular}

Table 4: Correlation between the Engagement Composite and the Poverty Beliefs Situational Composite

55
56
57
58
59
60

Overall ENG US


$\begin{array}{llll}\text { Engagement Composite } & .20^{*} & .29^{*} & .18\end{array}$

${ }^{*} p<.01$

10

11

12

13

14

15

16

17

18

19 